\title{
Progesterone impairs Herceptin effect on breast cancer cells
}

\author{
KAMILA KITOWSKA ${ }^{1}$, AGNIESZKA KOWALSKA ${ }^{1}$, MAGDALENA MIESZKOWSKA ${ }^{1}$, DOMINIKA PIASECKA ${ }^{2}$, \\ ANDRZEJ C. SKLADANOWSKI ${ }^{1}$, HANNA M. ROMANSKA ${ }^{2}$ and RAFAL SADEJ ${ }^{1}$ \\ ${ }^{1}$ Department of Molecular Enzymology, Intercollegiate Faculty of Biotechnology, University of Gdansk and Medical \\ University of Gdansk, Gdansk 80-210; ${ }^{2}$ Department of Pathology, Medical University of Lodz, Lodz 90-410, Poland
}

Received April 17, 2017; Accepted October 16, 2017

DOI: $10.3892 / \mathrm{ol} .2017 .7493$

\begin{abstract}
Breast cancer (BCa) is the most common cancer affecting women worldwide. Overexpression of human epidermal growth factor receptor 2 (HER2) occurs in $\sim 20-25 \%$ of invasive ductal breast carcinomas and is associated with the more aggressive phenotype. Herceptin, a humanized antibody against HER2, is a standard therapy in HER2-overexpressing cases. Approximately one-third of patients relapse despite treatment. Therefore numerous studies have investigated the molecular mechanisms associated with Herceptin resistance. An interaction between HER2 signalling and steroid hormone receptor signalling pathways has been previously investigated, but the effect of this relationship on Herceptin resistance has never been studied. The present study analysed an impact of the steroid hormone, progesterone (PG), on Herceptin-dependent cell growth inhibition. Results indicated that Herceptin-inhibited proliferation of breast cancer cell lines overexpressing HER2 (BT474 and MCF/HER2) in 3D culture is abolished by PG. Furthermore, results demonstrated that PG led to the activation of HER2/HER3-mediated signalling. Moreover, PG treatment induced a shift of Herceptin-dependent cell cycle arrest in $G_{1}$ phase towards $S$ and $G_{2}$ phases with concomitant upregulation of cyclin-dependent kinase 2 (CDK2) and downregulation of CDK inhibitor $\mathrm{p} 27^{\mathrm{Kip} 1}$. These results demonstrate for the first time PG involvement in the failure of Herceptin treatment in vitro. The present observations suggest that cross-talk between PG- and HRG/HER2-initiated signalling pathways may lead to the acquisition of resistance to Herceptin in patients with $\mathrm{BCa}$.
\end{abstract}

Correspondence to: Dr Kamila Kitowska or Dr Rafal Sadej, Department of Molecular Enzymology, Intercollegiate Faculty of Biotechnology, University of Gdansk and Medical University of Gdansk, Marii Skłodowskiej-Curie 3A, Gdansk 80-210, Poland E-mail: kkitowska@gumed.edu.pl

E-mail: rsadej@gumed.edu.pl

Key words: progesterone, human epidermal growth factor receptor 2, breast cancer, Herceptin resistance

\section{Introduction}

Overexpression of human epidermal growth factor receptor 2 (HER2) occurs in approximately $20-25 \%$ of invasive ductal breast carcinomas (BCa). It is associated with increased metastatic potential and poor prognosis (1). HER2 belongs to the receptor tyrosine kinases (RTK) HER family that comprises three other members (HER1/EGFR, HER3, HER4), which require specific ligand binding for activation. In contrast, no ligand has been identified for HER2 yet. Overexpressed HER 2 was found to be constitutively phosphorylated in both BCa cell lines and tumours (2). HER 2 forms homodimers or heterodimers with other ligand-activated members of the HER family (3). HER2/HER3 heterodimer has been demonstrated as the most potent oncogenic unit in HER2-positive BCa (4).

Herceptin (Trastuzumab) is a humanized antibody directed against the extracellular domain of HER2 and routinely used for the treatment of HER2-overexpressing BCa patients. The mechanism of Herceptin-mediated cell death is complex and involves antibody-dependent cell-mediated cytotoxicity, induction of apoptosis, inactivation of HER 2 homodimerization and abrogation of HER2-triggered cell signalling (5-7). Clinical data showed that some patients either originally do not respond to Herceptin or become resistant during the treatment $(8,9)$. There is a growing evidence demonstrating the interaction between HER2 signalling and estrogen receptor (ER) pathway (10). PR (progesterone receptor), one of the ER-dependent genes, together with its cognate ligand-progesterone (PG), play a critical role in breast cancer development and progression (11-13). A cross-talk between steroid hormones and RTK (e.g., HER receptor)-initiated signalling has a bidirectional nature. Steroid hormone receptors may activate either RTKs or their downstream signalling pathways $(14,15)$. Balañá et al $(16)$ demonstrated in MPA (medroxyprogesterone acetate-synthetic progestin)-induced mice mammary adenocarcinomas, an interaction between progestins- and heregulin (HRG) (HER1/EGFR and HER3 ligand)-dependent signalling. Conversely, RTK-triggered pathways are able to modulate steroid receptor's activity (17). HER 2 overexpression has been linked with resistance to endocrine therapies both in vitro and in vivo (10). Consistently, there are studies showing that ER activity can function as an escape pathway for $\mathrm{ER}^{+} / \mathrm{HER} 2^{+}$cells exposed to anti-HER2 treatment (18). The role of PG/PR in the process of resistance to anti-HER2 therapies remains elusive. Taking into 
consideration reciprocal interactions between steroid hormone receptors and HER2-mediated signalling, we hypothesised that PG may affect anti-proliferative effect of Herceptin.

Herein we showed for the first time that PG may attenuate the efficacy of HER2-targeted anticancer compounds. We demonstrated that PG impaired Herceptin-mediated anti-proliferative action in HER2-overexpressing cell lines and led to activation of HER2/HER3-triggered signalling. Moreover, PG reversed Herceptin-induced cell cycle arrest in $\mathrm{G}_{0} / \mathrm{G}_{1}$ cell cycle phase with concomitant upregulation of cyclin-dependent kinase 2 (CDK2) and downregulation of CDK inhibitor p27 ${ }^{\mathrm{Kip} 1}$. These findings indicate complexity of the mechanism responsible for resistance to Herceptin and suggest that targeting of multiple signalling pathways may result in better therapeutic effects.

\section{Materials and methods}

Cell lines, antibodies, reagents. BT474 (cat. no. HTB-20 ${ }^{\mathrm{TM}}$ ) and MCF7 (cat. no. HTB-22 $2^{\mathrm{TM}}$ ) cell lines were obtained from ATCC, cells from passages 86 through 106 and 71 through 91, respectively, were used in these investigations. BT474 cells were maintained in RPMI-1640 supplemented with $5 \mu \mathrm{g} / \mathrm{ml}$ insulin, whereas MCF7 cells were grown in DMEM. Media contained $10 \%$ of FBS and penicillin/streptomycin $(100 \mathrm{U} / \mathrm{ml} / 100 \mu \mathrm{g} / \mathrm{ml})$. All cell culture reagents were purchased from Sigma-Aldrich (St. Louis, MO, USA) or HyClone (Logan, UT, USA). Cells were cultured for a maximum of 3-4 months post resuscitation and regularly tested for mycoplasma contamination.

Mouse monoclonal antibody against $\beta$-actin (A5316, dilution 1:1,000) was obtained from Sigma-Aldrich. All the remaining antibodies were from Cell Signaling Technology, Inc. (Danvers or Beverly, MA, USA): Rabbit monoclonal anti-CDK2 (no. 2546, dilution 1:1,000), rabbit monoclonal anti-HER2/ErbB2 (no. 4290, dilution 1:1,000), rabbit polyclonal anti-HER2/ErbB2-Tyr877 (no. 2241, dilution 1:1,000), rabbit polyclonal anti-HER2/ErbB2-Tyr1221/1222 (no. 2249, dilution 1:1,000), rabbit polyclonal anti-HER2/ErbB2-Tyr1248 (no. 2247, dilution 1:1,000), rabbit monoclonal anti-HER3/ErbB3 (no. 4754, dilution 1:1,000), rabbit monoclonal anti-HER3/ErbB3-Tyr1289 (no. 4791, dilution 1:1,000), rabbit polyclonal anti-heregulin (no. 2573, dilution 1:1,000) and rabbit monoclonal anti-p27 $7^{\text {Kip1 }}$ (no. 3686, dilution 1:1,000). PG was purchased from Sigma-Aldrich. Herceptin was obtained from Genetech.

Western blot analysis. Cells were grown in monolayer to $60-70 \%$ confluency, scraped in cold PBS and lysed with Laemmli buffer (2X concentrated) supplemented with: $2 \mathrm{mM}$ PMSF, $10 \mu \mathrm{g} / \mathrm{ml}$ aprotinin, $10 \mu \mathrm{g} / \mathrm{ml}$ leupeptin, 5 mM EGTA, $1 \mathrm{mM}$ EDTA, $2 \mathrm{mM} \mathrm{Na}_{4} \mathrm{P}_{2} \mathrm{O}_{7}, 5 \mathrm{mM} \mathrm{NaF}$ and $5 \mathrm{mM} \mathrm{Na}_{3} \mathrm{VO}_{4}$. Samples containing equal amounts of protein per lane were loaded, resolved in SDS-PAGE and then transferred onto nitrocellulose membrane. The membranes were incubated for $1 \mathrm{~h}$ in $5 \%$ skimmed milk and probed overnight with specific primary antibodies at $4^{\circ} \mathrm{C}$. Secondary goat anti-rabbit (A9169, 1:20,000) or rabbit anti-mouse (A9044, 1:10,000) antibodies conjugated with HRP (Sigma-Aldrich) and Western Lightning Plus-ECL (PerkinElmer, Inc., Waltham, MA, USA) were used to visualize specific proteins.
Table I. Effect of PG and/or Herceptin treatment on cell cycle.

\begin{tabular}{lc}
\hline BT474 & \% of cells in $\mathrm{G}_{0}-\mathrm{G}$ \\
\hline CTR & $72,85 \pm 2,31$ \\
PG & $66,47 \pm 3,80$ \\
HERCEPTIN & $79,91 \pm 1,63$ \\
PG+HERCEPTIN & $73,12 \pm 2,51$ \\
\hline
\end{tabular}

CTR, untreated cells; PG, progesterone.

Cell growth in three-dimensional Matrigel. The three-dimensional cell growth assay was performed in a Matrigel matrix (BD Biosciences, Heidelberg, Germany) as previously described (19). Briefly, $1 \times 10^{3}$ cells were resuspended in $40 \mu \mathrm{l}$ of Matrigel ( $\sim 2 \mathrm{mg}$ of total protein $/ \mathrm{ml})$, placed into 12-well tissue culture plates followed by $30 \mathrm{~min}$ incubation at $37^{\circ} \mathrm{C}$ for Matrigel to solidify. 3D cultures were then covered with regular medium supplemented, when appropriate, with $\mathrm{PG}$ $(100 \mathrm{nM})$ and/or Herceptin $(10 \mu \mathrm{g} / \mathrm{ml})$. Media were refreshed every 3 days. To evaluate cell growth, a mean colony diameter was measured for, at least, 50 randomly chosen colonies after 10 days of culture with ZEISS PrimoVert microscope and ImageJ software and the mean colony volume was determined. Each experiment was repeated, at least, three times.

Development of HER2 overexpression in MCF7 cells. MCF7 cells were plated in $60 \mathrm{~mm}$ plates and grown in the monolayer to approximately $50 \%$ confluency. Medium was refreshed $1 \mathrm{~h}$ before transfection. Cells were transfected with $1 \mu \mathrm{g}$ of $\mathrm{pBABE}-$ puro-ERBB2 plasmid (no. 40978; Addgene, Inc., Cambridge, MA, USA) (20) containing full-length HER2 cDNA coding region) in serum free DMEM applying TurboFect reagent, according to the manufacturer's instructions (Thermo Fisher Scientific, Waltham, MA, USA). Selection of MCF7 stably expressing ERBB2 was carried out in $2 \mu \mathrm{g} / \mu 1$ puromycin (Gibco, Grand Island, NY, USA).

Flow cytometry. Cells were grown in 12-well plates in the monolayer up to $50 \%$ of confluency and serum starved overnight. Then cells were treated with PG (100 nM) and/or Herceptin $(10 \mu \mathrm{g} / \mathrm{ml}), 24 \mathrm{~h}$ after stimulation, cells were trypsinized, washed twice with ice-cold PBS, fixed in $70 \%$ ethanol at $-20^{\circ} \mathrm{C}$ for $15 \mathrm{~min}$, resuspended in RNaseA $1 \mathrm{mg} / \mathrm{ml}$ (EURX Ltd. Gdansk, Poland) and stained with propidium iodide $(2,5 \mu \mathrm{g} / \mathrm{ml})$. Cell cycle was analysed with BD LSR II flow cytometer (BD Biosciences).

Stimulation with growth factors, treatment with Herceptin, signalling analyses. For analysis of growth factors-triggered signalling, cells were serum-starved overnight before growth factors were added. Cells were stimulated with PG (100 nM), Herceptin $(10 \mu \mathrm{g} / \mathrm{ml})$ for indicated periods of time.

Statistical analysis. Data are expressed as means \pm SD from at least three independent experiments. Comparative data were analysed with the unpaired Student's t-test using the STATISTICA software (v.10; StatSoft, Inc., Tulsa, OK, USA). 
A
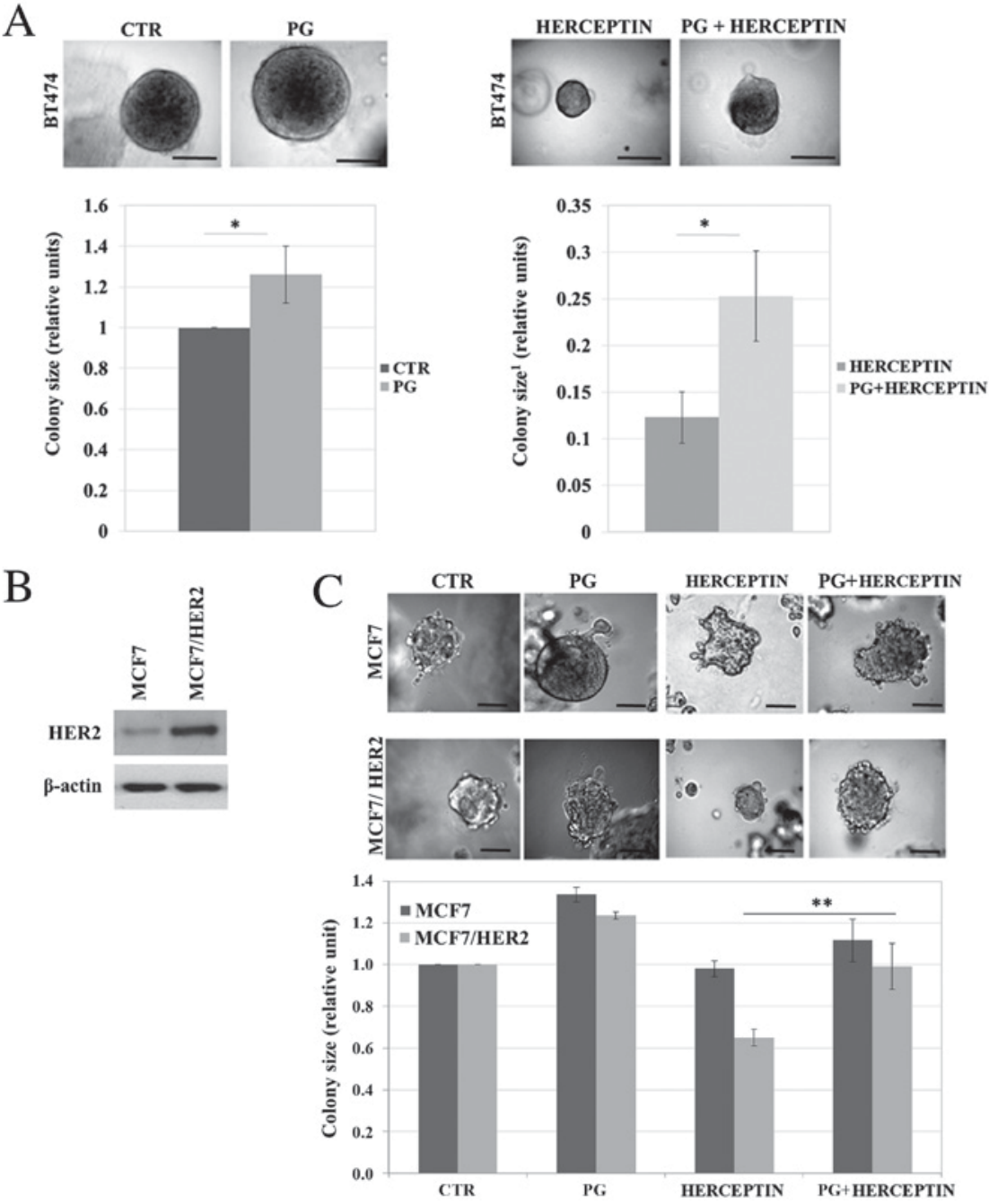

Figure 1. PG affects Herceptin-mediated cell growth inhibition. (A) BT474 cells were cultured in 3D Matrigel in the presence of PG (100 nM) and/or Herceptin $(10 \mu \mathrm{g} / \mathrm{ml})$. (B) HER2-overexpressing cell line variant termed MCF7/HER2 was derived from MCF7 cells (transfected with pBABEpuro-ERBB2). Expression level of HER2 was analysed by western blotting in MCF7 and MCF7/HER2 cells. (C) MCF7 and MCF7/HER2 cells were cultured in 3D Matrigel in the presence of PG $(100 \mathrm{nM})$ and/or Herceptin $(10 \mu \mathrm{g} / \mathrm{ml})$. Representative pictures of colonies (for A and C) were taken after 10 days of growth. Magnification x200. Colonies size was determined with ImageJ software. The values presented are means of $\pm \mathrm{SD}(\mathrm{n}=3),{ }^{*} \mathrm{P}<0,05 ;{ }^{* *} \mathrm{P}<0,01$. Scale bar $100 \mu \mathrm{m}$. ${ }^{1}$ Relative unit=ratio to control (mean colony size of untreated cells).

Two-sided $\mathrm{P}<0.05$ was considered to indicate a statistically significant difference.

\section{Results}

PG impairs Herceptin effect on HER2-overexpressing cells growth. To investigate the potential impact of PG on HER2-overexpressing cells response to Herceptin treatment we evaluated BT474 BCa cells $\left(\mathrm{PR}^{+}\right.$, HER $\left.{ }^{++}\right)$growth in three-dimensional Matrigel. We found a modest ( 28\%) PG-triggered stimulation of cell proliferation (reflected in colony size) (Fig. 1A, left panel). As expected Herceptin significantly inhibited colonies growth $(\sim 88 \%, \mathrm{P}<0,05)$. Importantly, Herceptin-mediated inhibition of growth was impaired by PG (Fig. 1A, right panel). To confirm these results we developed a HER2-overexpressing variant (MCF/HER2) of MCF7 BCa cells (representing luminal A subtype, $\mathrm{ER}^{+} / \mathrm{PR}^{+} / \mathrm{HER} 2^{\text {low }}$ ) by transient transfection with plasmid coding erbB2 gene (Fig. 1B). Growth analysis in three-dimensional Matrigel revealed that overexpression of
HER2 resulted in sensitization of MCF7 cells to Herceptin (Fig. 1C). Although PG had modest growth stimulatory effect on both MCF7 and MCF7/HER2 cells, it clearly exerted a significant protective effect against Herceptin treatment $\left({ }^{*} \mathrm{P}<0,05\right)$.

$P G$ induces both activation and expression of HER2/HER3 signalling. To analyse mechanisms of PG action on HER2 and HER3 function we treated BT474 cells with PG (up to $60 \mathrm{~min}$ ) and analysed HER2/HER3 activation. It was observed that PG triggered rapid phosphorylation of Tyr1221/1222, Tyr1248 and Tyr877 of HER2 (Fig. 2A). In addition, PG induced Tyr1289 HER3 phosphorylation. Prolonged exposure of BT474 cells to PG (up to $72 \mathrm{~h}$ ) showed that PG not only regulated the activation of HER 2 and HER 3 but also caused a gradual increase in their expression (Fig. 2B). In addition, PG enhanced the expression of heregulin $\beta-1$, a HER3 ligand, the binding of which is known to promote HER2/HER3 heterodimerization (21). Heregulin $\beta-1$ reached the peak of expression after $48 \mathrm{~h}$ of exposure to PG (Fig. 2B). 


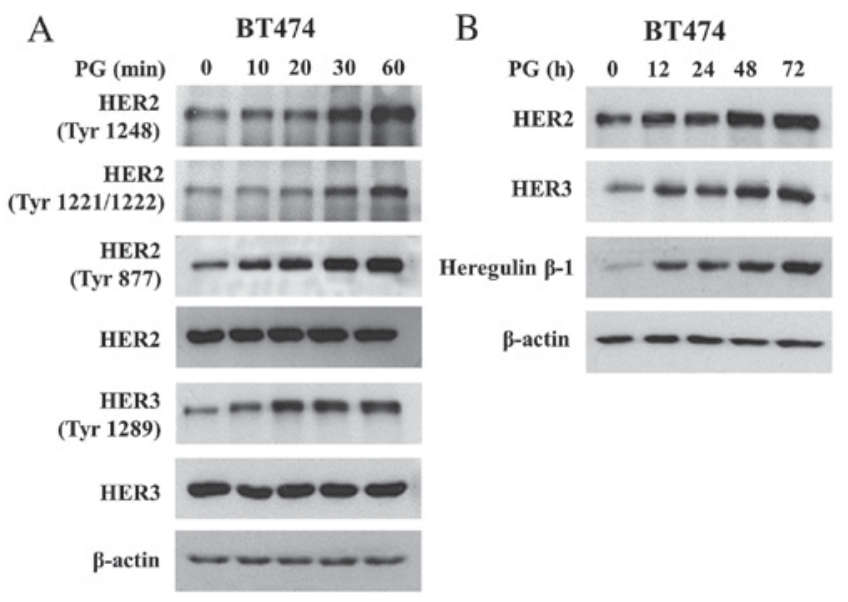

Figure 2. PG impact on HER2/HER3 activation and expression. (A) Level of HER2, HER3 phosphorylation was analysed by western blotting in serum starved BT474 cells treated with PG $(100 \mathrm{nM})$ for 10, 20, 30 and $60 \mathrm{~min}$. (B) Expression levels of HER2, HER3 and heregulin $\beta-1$ were evaluated by western blotting in serum-starved BT474 cells treated with PG $(100 \mathrm{nM})$ for $12,24,48$ and $72 \mathrm{~h}$.

$P G$ reverses Herceptin-induced cell cycle arrest. To further assess the impact of PG on cell response to Herceptin, cell cycle was analysed. Herceptin promoted the accumulation of cells in $G_{0} / G_{1}$ phase (Fig. 3A; Table I), which was reverted by the PG treatment (observed as a shift towards $\mathrm{S}$ and $\mathrm{G}_{2} / \mathrm{M}$ phase). Analysis of PG-mediated mechanism of cell transition through $G_{1}$ to $S$ demonstrated that $P G$ attenuated both Herceptin-induced upregulation of p27 ${ }^{\mathrm{Kip} 1}$ and downregulation of CDK2 (Fig. 3B). These findings indicate that Herceptin-triggered cell cycle arrest at $G_{1}$ phase, which is most likely mediated by $\mathrm{p} 27^{\mathrm{Kip} 1}$, is abrogated by PG.

\section{Discussion}

HER2 gene amplification and protein overexpression have been found to be an adverse prognostic factor in invasive ductal breast cancer. Herceptin, a monoclonal antibody directed against domain IV of HER2, was approved in 1998 for the treatment of HER2-amplified cancers $(8,9)$. Despite the undisputed benefits of Herceptin-based therapy, clinical data show that the development of resistance to the drug remains an unsolved problem. Herceptin anticancer mechanism is complex and not fully elucidated. It has been well documented that resistance to Herceptin arises from the activation of alternative pathways, including ER-dependent signalling, which becomes the dominant driver of cell proliferation and survival (22-25). Wang et al (18) demonstrated that in $\mathrm{ER}^{+} / \mathrm{HER} 2^{+}$tumor cells, increased expression of ER as well as its downstream target $\mathrm{Bcl} 2$, was associated with resistance to anti-HER2 therapy. ER was proved to enhance PR expression (26) and physically interact with PR, which promoted breast cancer cells proliferation (27). As ER and PR share similar signalling pathways (28), we hypothesized that PR activity may affect Herceptin anti-proliferative action. Herein, we demonstrated for the first time that Herceptin-mediated growth inhibition was significantly impaired by PG. We observed that a short stimulation with PG (up to $60 \mathrm{~min}$ ) led to HER2/HER3 activation in BT474 cells. On the other hand, prolonged stimulation
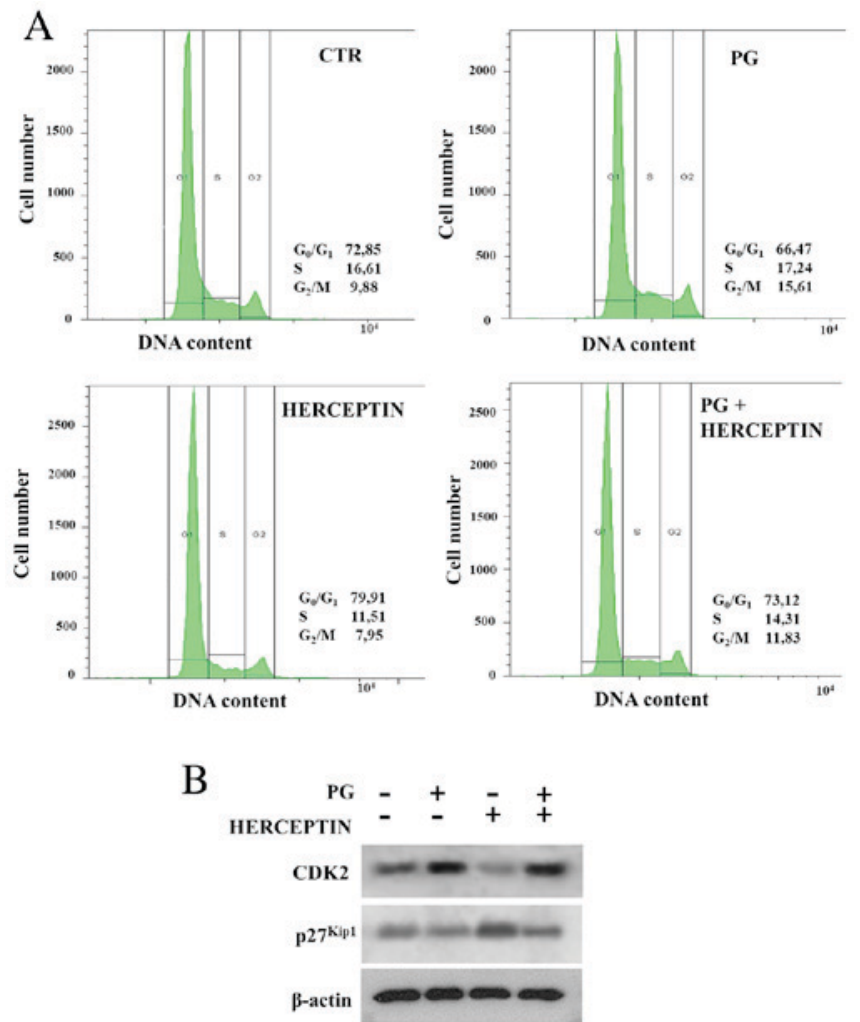

Figure 3. Cell cycle analysis of PG and/or Herceptin treated cells. BT474 cells were serum starved and stimulated with PG (100 nM) and/or Herceptin $(10 \mu \mathrm{g} / \mathrm{ml})$ for $24 \mathrm{~h}$. (A) Cells were stained with propidium iodide and cell cycle was analysed by flow cytometry. Data from three experiments. (B) CDK2 and $\mathrm{p} 27^{\mathrm{Kip} 1}$ expression levels were evaluated by western blot analysis.

(up to $72 \mathrm{~h}$ ) induced not only the expression of both receptors (i.e., HER2 and HER3) but also that of heregulin, a ligand for HER3. Our results are in accordance with the data presenting upregulation of heregulin in MPA (synthetic PG)-induced mammary tumours (16) and its impact on cell proliferation. Taken together, it can be speculated that PG action towards the anti-proliferative effect of Herceptin may involve PG-promoted increase of expression of heregulin, which, by binding to HER3, induces HER2/HER3 heterodimerization and subsequent activation of downstream signals. Our data demonstrated that PG also abolished Herceptin-mediated cell-cycle arrest in $G_{0}-G_{1}$ phase. PG-promoted cell shift towards $\mathrm{S}$ and $\mathrm{G}_{2} / \mathrm{M}$ phase was observed with a concomitant upregulation of CDK2 and downregulation of $\mathrm{p} 27^{\mathrm{Kip} 1}$. There seems to be a reciprocal regulation of PR-CDK2 activities, as CDK2 was shown to phosphorylate PR (8 out of 14 PR phosphorylation sites are known to be targeted by CDK2) $(29,30)$ and increase PR transcriptional function (31).

Steroid hormones play a critical role in breast carcinogenesis (32-34). Although the relationship between the level of circulating estrogen/PG and breast cancer risk has been extensively studied, the effect of steroids on the efficacy of anti-HER2 BCa therapy has not been greatly explored. Our findings provide support for the hypothesis that, in steroid hormone receptors-positive $\mathrm{BCa}$, acquisition of resistance to Herceptin might be triggered by $\mathrm{PG}$. This finding seems to be important especially for premenopausal women, who are exposed to periodically increased level of PG. Our results 
reveal a new level of complexity of resistance to Herceptin mechanisms and suggest that combined therapy involving Herceptin and PR antagonists may have potential benefits for HER2-overexpressing $\mathrm{BCa}$ in premenopausal patients.

\section{Acknowledgements}

pBABEpuro-ERBB2 (Addgene plasmid no. 40978) was a gift from Matthew Meyerson (Dana-Farber Cancer Institute). The research leading to these results has received funding from National Science Centre-UMO-2012/06/M/NZ3/00023 (to RS), the European Union Seventh Framework Programme (grant agreement no 316094-MOBI4Health project) and Polish Ministry of Science and Higher Education from science funds 2013-2016 within co-funded projects. Kamila Kitowska has been supported by the MOBI4health project.

\section{References}

1. Gutierrez $\mathrm{C}$ and Schiff R: HER2: Biology, detection, and clinical implications. Arch Pathol Lab Med 135: 55-62, 2011.

2. DiGiovanna MP, Chu P, Davison TL, Howe CL, Carter D, Claus EB and Stern DF: Active signaling by HER-2/neu in a subpopulation of HER-2/neu-overexpressing ductal carcinoma in situ: Clinicopathological correlates. Cancer Res 62: 6667-6673, 2002.

3. Graus-Porta D, Beerli RR, Daly JM and Hynes NE: ErbB-2, the preferred heterodimerization partner of all ErbB receptors, is a mediator of lateral signaling. EMBO J 16: 1647-1655, 1997.

4. Holbro T, Beerli RR, Maurer F, Koziczak M, Barbas CF III and Hynes NE: The ErbB2/ErbB3 heterodimer functions as an oncogenic unit: ErbB2 requires ErbB3 to drive breast tumor cell proliferation. Proc Natl Acad Sci USA 100: 8933-8938, 2003

5. Sliwkowski MX, Lofgren JA, Lewis GD, Hotaling TE, Fendly BM and Fox JA: Nonclinical studies addressing the mechanism of action of trastuzumab (Herceptin). Semin Oncol 26 (4 Suppl 12): S60-S70, 1999

6. Baselga J, Albanell J, Molina MA and Arribas J: Mechanism of action of trastuzumab and scientific update. Semin Oncol 28 (5 Suppl 16): S4-S11, 2001

7. Luque-Cabal M, García-Teijido P, Fernández-Pérez Y, Sánchez-Lorenzo L and Palacio-Vázquez I: Mechanisms behind the resistance to trastuzumab in HER2-amplified breast cancer and strategies to overcome it. Clin Med Insights Oncol 10 (Suppl 1): S21-S30, 2016.

8. Vogel CL, Cobleigh MA, Tripathy D, Gutheil JC, Harris LN, Fehrenbacher L, Slamon DJ, Murphy M, Novotny WF, Burchmore M, et al: Efficacy and safety of trastuzumab as a single agent in first-line treatment of HER2-overexpressing metastatic breast cancer. J Clin Oncol 20: 719-726, 2002.

9. Cobleigh MA, Vogel CL, Tripathy D, Robert NJ, Scholl S Fehrenbacher L, Wolter JM, Paton V, Shak S, Lieberman G and Slamon DJ: Multinational study of the efficacy and safety of humanized anti-HER2 monoclonal antibody in women who have HER2-overexpressing metastatic breast cancer that has progressed after chemotherapy for metastatic disease. J Clin Oncol 17: 2639-2648, 1999.

10. Shou J, Massarweh S, Osborne CK, Wakeling AE, Ali S, Weiss $H$ and Schiff R: Mechanisms of tamoxifen resistance: Increased estrogen receptor-HER $2 /$ neu cross-talk in ER/HER2-positive breast cancer. J Natl Cancer Inst 96: 926-935, 2004.

11. Schairer C, Lubin J, Troisi R, Sturgeon S, Brinton L and Hoover R: Menopausal estrogen and estrogen-progestin replacement therapy and breast cancer risk. JAMA 283: 485-491, 2000

12. Soyal S, Ismail PM, Li J, Mulac-Jericevic B, Conneely OM and Lydon JP: Progesterone's role in mammary gland development and tumorigenesis as disclosed by experimental mouse genetics. Breast Cancer Res 4: 191-196, 2002.

13. Graham JD and Clarke CL: Physiological action of progesterone in target tissues. Endocr Rev 18: 502-519, 1997.
14. Béguelin W, Díaz Flaqué MC, Proietti CJ, Cayrol F, Rivas MA, Tkach M, Rosemblit C, Tocci JM, Charreau EH, Schillaci R and Elizalde PV: Progesterone receptor induces ErbB-2 nuclear translocation to promote breast cancer growth via a novel transcriptional effect: ErbB-2 function as a coactivator of Stat3. Mol Cell Biol 30: 5456-5472, 2010.

15. Stoica GE, Franke TF, Wellstein A, Czubayko F, List HJ, Reiter R, Morgan E, Martin MB and Stoica A: Estradiol rapidly activates Akt via the ErbB2 signaling pathway. Mol Endocrinol 17: 818-830, 2003.

16. Balañá ME, Lupu R, Labriola L, Charreau EH and Elizalde PV: Interactions between progestins and heregulin (HRG) signaling pathways: HRG acts as mediator of progestins proliferative effects in mouse mammary adenocarcinomas. Oncogene 18: 6370-6379, 1999

17. Labriola L, Salatino M, Proietti CJ, Pecci A, Coso OA, Kornblihtt AR, Charreau EH and Elizalde PV: Heregulin induces transcriptional activation of the progesterone receptor by a mechanism that requires functional ErbB-2 and mitogen-activated protein kinase activation in breast cancer cells. Mol Cell Biol 23: 1095-1111, 2003.

18. Wang YC, Morrison G, Gillihan R, Guo J, Ward RM, Fu X, Botero MF, Healy NA, Hilsenbeck SG, Phillips GL, et al: Different mechanisms for resistance to trastuzumab versus lapatinib in HER2-positive breast cancers-role of estrogen receptor and HER2 reactivation. Breast Cancer Res 13: R121, 2011.

19. Sadej R, Romanska H, Baldwin G, Gkirtzimanaki K, Novitskaya V, Filer AD, Krcova Z, Kusinska R, Ehrmann J, Buckley CD, et al: CD151 regulates tumorigenesis by modulating the communication between tumor cells and endothelium. Mol Cancer Res 7: 787-798, 2009.

20. Greulich H, Kaplan B, Mertins P, Chen TH, Tanaka KE, Yun CH, Zhang X, Lee SH, Cho J, Ambrogio L, et al: Functional analysis of receptor tyrosine kinase mutations in lung cancer identifies oncogenic extracellular domain mutations of ERBB2. Proc Natl Acad Sci USA 109: 14476-14481, 2012.

21. Weiss FU, Wallasch C, Campiglio M, Issing W and Ullrich A: Distinct characteristics of heregulin signals mediated by HER3 or HER4. J Cell Physiol 173: 187-195, 1997.

22. Nagata Y, Lan KH, Zhou X, Tan M, Esteva FJ, Sahin AA, Klos KS, Li P, Monia BP, Nguyen NT, et al: PTEN activation contributes to tumor inhibition by trastuzumab, and loss of PTEN predicts trastuzumab resistance in patients. Cancer Cell 6: 117-127, 2004.

23. Berns K, Horlings HM, Hennessy BT, Madiredjo M, Hijmans EM, Beelen K, Linn SC, Gonzalez-Angulo AM, Stemke-Hale K, Hauptmann M, et al: A functional genetic approach identifies the PI3K pathway as a major determinant of trastuzumab resistance in breast cancer. Cancer Cell 12: 395-402, 2007.

24. Nahta R, Yuan LX, Zhang B, Kobayashi R and Esteva FJ: Insulin-like growth factor-I receptor/human epidermal growth factor receptor 2 heterodimerization contributes to trastuzumab resistance of breast cancer cells. Cancer Res 65: 11118-11128, 2005.

25. Scaltriti M, Eichhorn PJ, Cortés J, Prudkin L, Aura C, Jiménez J, Chandarlapaty S, Serra V, Prat A, Ibrahim YH, et al: Cyclin E amplification/overexpression is a mechanism of trastuzumab resistance in HER2 ${ }^{+}$breast cancer patients. Proc Natl Acad Sci USA 108: 3761-3766, 2011.

26. Horwitz KB and McGuire WL: Estrogen control of progesterone receptor in human breast cancer. Correlation with nuclear processing of estrogen receptor. J Biol Chem 253: 2223-2228, 1978.

27. Daniel AR, Gaviglio AL, Knutson TP, Ostrander JH, D'Assoro AB, Ravindranathan P, Peng Y, Raj GV, Yee D and Lange CA: Progesterone receptor-B enhances estrogen responsiveness of breast cancer cells via scaffolding PELP1and estrogen receptor-containing transcription complexes. Oncogene 34: 506-515, 2015.

28. Ballaré C, Uhrig M, Bechtold T, Sancho E, Di Domenico M, Migliaccio A, Auricchio F and Beato M: Two domains of the progesterone receptor interact with the estrogen receptor and are required for progesterone activation of the c-Src/Erk pathway in mammalian cells. Mol Cell Biol 23: 1994-2008, 2003.

29. Knotts TA, Orkiszewski RS, Cook RG, Edwards DP and Weigel NL: Identification of a phosphorylation site in the hinge region of the human progesterone receptor and additional amino-terminal phosphorylation sites. J Biol Chem 276: 8475-8483, 2001. 
30. Zhang Y, Beck CA, Clement JP IV, Prendergast P, Yip TT, Hutchens TW, Edwards DP and Weigel NL: Phosphorylation of human progesterone receptor by cyclin-dependent kinase 2 on three sites that are authentic basal phosphorylation sites in vivo. Mol Endocrinol 11: 823-832, 1997.

31. Pierson-Mullany LK and Lange CA: Phosphorylation of progesterone receptor serine 400 mediates ligand-independent transcriptional activity in response to activation of cyclin-dependent protein kinase 2. Mol Cell Biol 24: 10542-10557, 2004.

32. Bernstein L: Epidemiology of endocrine-related risk factors for breast cancer. J Mammary Gland Biol Neoplasia 7: 3-15, 2002.
33. Campagnoli C, Clavel-Chapelon F, Kaaks R, Peris C and Berrino F: Progestins and progesterone in hormone replacement therapy and the risk of breast cancer. J Steroid Biochem Mol Biol 96: 95-108, 2005.

34. Zhou W and Slingerland JM: Links between oestrogen receptor activation and proteolysis: Relevance to hormone-regulated cancer therapy. Nat Rev Cancer 14: 26-38, 2014. 